\title{
TOLERANSI DALAM KEHIDUPAN MULTIKULTUR DI SMP NEGERI 2 ARUT SELATAN
}

\author{
Muslimah \\ Dosen Pascasarjana IAIN Palangkaraya \\ Jl. G. Obos VI, Kota Palangka Raya
}

\begin{abstract}
The differences in religions and faith in a public educational institution is inevitable. If the tolerance is not implemented, it will lead to the intolerance which impeding an institution achieves its goal as a shared one. This study aims to know the forms of tolerance in SMP Negeri 2 Arut Selatan. This qualitative method uses a method of observing participants, in-depth interviews, and documentations which is analysed from the beginning to the end of the report. The results of this study indicate that the intra and inter-religious tolerance in SMP Negeri 2 Arut Selatan was implemented in the forms of mutual understanding and respect, as well as team-work oriented commitments. It can be seen from the way of facilitating and giving a freedom in worship; celebrating a religious holydays together within the customary limitations; visiting and congratulating some believers; and appreciating the applicable rules of permissible (halal) and forbidden (haram) food and beverages for Muslims.
\end{abstract}

Kata Kunci: toleransi, kehidupan multikultur

\section{A. Pendahuluan}

Karakteristik bangsa Indonesia, memang berbeda jika dibanding dengan bangsa-bangsa lain di dunia ini, diantara fakta menunjukkan jika "terbesar memeluk agama Islam, agama lain yang dianut adalah Katolik, Protestan, Hindu, Budha serta lainnya. Jumlah penduduk Indonesia menghuni 6.000 pulau". ${ }^{1}$ Artinya, secara faktual dengan penduduk Indonesia yang demikian telah mendasarkan diri pada nilai-nilai agama yang menjadi keyakinan pemeluk agama masing-masing. Kondisi ini juga tergambar pada lembaga pendidikan umum, adalah sebuah keniscayaan berbeda karena di dalamnya terdiri dari berbagai pemeluk agama. Jika perbedaan tersebut

${ }^{1}$ Lembaga Administrasi Negara Republik Indonesia, Kepemimpinan dalam Keragaman Budaya, Tidak diterbitkan, (Jakarta: Modul Diklatpim Tingkat III, 2008), h. 1. 
diberdayakan sesuai kompetensinya termasuk bertoleransi, tentu menjadi sumber kekuatan dan kekayaan.

Pelaksanaan toleransi di lembaga pendidikan/ sekolah memang bukan hal yang gampang jika tidak didasari oleh nilai-nilai kebaikan yang terdapat pada agama masing-masing pemeluk. Minimal ada tiga unsur yang terlibat di dalamnya, yaitu: pendidik, tenaga kependidikan dan siswa. Karena sekolah adalah lembaga pendidikan yang bersifat organisasional dan terstruktur, serta tata laksana yang terpola dengan aktivitas yang ketergantungan pada tujuan tertentu. Made Pidarta menguatkan dengan pendapat bahwa mengelola pendidikan tidaklah sama dengan mengelola bisnis atau pemerintahan. Mengelola pendidikan perlu banyak strategi, pendekatan, metode dan kiat, sebab bermuara pada keberhasilan perkembangan semua peserta didik. ${ }^{2}$

Oleh karena itu, penanaman nilai-nilai agama agar menjadi culture di sekolah harus menjadi bagian dari strategi atau metode mengelola sekolah. Jangan sampai agama hanya dipahami sebagai boleh dan tidak boleh, pahala dan dosa yang lepas dari keuniversalan agama, karena pemahaman yang tidak universal atau tidak kaffah dalam beragama, bisa berakibat kehilangan fungsi dan peran yang akhirnya dapat menjadi distorsi, yaitu "pembudayaan agama tidak hanya bersifat ekslusif saja, tetapi betul-betul artikulatif, dengan efek yang muncul sebagai hasil yang sama sekali di luar tujuan yang diekspresikan".3

Demikian halnya dengan di Sekolah Menengah Pertama Negeri 2 Arut Selatan, selanjutnya disebut SMP Negeri 2 Arut Selatan adalah sekolah yang dalam pengelolaannya berdasarkan demokratis, masing-masing sudah memahami sistem kerja masing-masing melalui garis komando. Pendidik, tenaga kependidikan dan siswanya terlihat dan dirasakan memahami perbedaan dan menerimanya sebagai

\footnotetext{
${ }^{2}$ Made Pidarta, Landas Kependidikan: Stimulus Ilmu Pendidikan Bercorak Indonesia, (Jakarta: Rineka Cipta, 2007), h. Xii.

${ }^{3}$ Wina Sanjaya, Kurikulum Pembelajaran, Teori dan Praktik Pengembangan Kurikulum Satuan Pendidikan, (Jakarta: Kencana Prenada Media Grouf, 2009), h. 26.
} 
sebuah keniscayaan berada di sekolah umum yang di dalamnya terdiri dari multi agama. Saling menghargai perbedaan dimaksud mereka aplikasikan di sekolah juga luar sekolah.

Aplikasi penghargaan perbedaan ditunjukkan dengan: penyediaan ruang/ kelas khusus untuk belajar agama masing-masing agama, bantuan dana dalam melaksanakan kegiatan keagamaan termasuk memperingati hari besar keagamaan; merekrut guru agama sesuai dengan latar belakang agama siswa; mengikutsertakan pendidik dan tenaga kependidikan dalam kegiatan hari besar keagamaan pada batas toleransi yang lazim; menyetarakan materi pelajaran agama seperti pelajaran lain dalam hal ujian praktik dan pengadaan alat peraga; menciptakan kenyamanan kebebasan menjalankan ibadah agama masing-masing warga sekolah.

Kenyataan di atas, menggambarkan implementasi toleransi umat beragama dan umat seagama di sekolah menjadi bagian dari nilai religious culture sekolah. Fakta ini menjadikan penulis tertarik untuk mengetahuinya lebih mendalam melalui penelitian berjudul Pengaruh Religious Culture Terhadap Manajemen Kinerja, dengan subfokus "toleransi dalam kehidupan multikultur di SMP Negeri 2 Arut Selatan".

Penulis mengangkat subfokus penelitian di atas karena: nilai ini yang nyata ada dan dirasakan oleh pendidik dan tenaga kependidikan yang bertugas di sekolah umum; serta, belum pernah ada yang melakukan penelitian dari masalah yang sama sebelumnya.

Memilih lokasi di SMP Negeri 2 Arut Selatan karena: keberadaan sekolah yang beroperasi lebih dari dua puluh tahun termasuk usia yang berpengalaman mengembangkan sekolah yang di dalamnya bersifat multi kultur dan belum pernah terjadi intoleransi; sekolah ini memiliki pendidik dan tenaga kependidikan dengan penganut agama yang hampir lengkap sebagaimana yang dilindungi undang-undang, yaitu agama: Islam, Protestan, Katolik, Hindu, Budha, dan Kong Hucu. 
Penelitian kualitatif ini digali dengan teknik pengumpulan data partisipant observation, indept interviu, dan study dokumenter. Selanjtnya, melakukan analisis data yang dilakukan selama proses penelitian berlangsung.

\section{B. Kajian Pustaka}

Toleransi adalah sebagai suatu pengakuan masyarakat majemuk yang mengakui perdamaian. Dalam kehidupan beragama, toleransi merupakan kenyataan bahwa banyak orang yang memeluk agama yang berbeda-beda sehingga perlu mengakuinya sebagai saudara se-Tuhan. ${ }^{4}$ Khusus di Indonesia, ada Kementerian Agama sebagai institusi pengayom umat, lebih memaknai kata toleransi pada keterlibatan yang aktif, dengan harapan setiap umat beragama dapat berinteraksi secara positif dalam lingkungan yang multikultural.

Kementerian Agama berharap dan mengupayakan agar umat beragama di Indoneisa bersedia menerima kenyataan pendapat yang berbeda-beda tentang kebenaran yang dianut pemeluk agama, bersikap menghargai keyakinan orang lain terhadap agamanya, juga dapat bersikap memberi kebebasan dalam menjalankan ajaran agamanya yang dianutnya, karena "sikap toleransi adalah sikap yang tidak menolak terhadap perbedaan-berpedaan dalam menjalankan agama masing-masing penganut agama". 5

Islam sendiri sudah mengatur pelaksanaan toleransi, untuk universal bersikap kepada agama lain dan sudah diatur secara i'tiqadi sebagai prinsip yang harus

${ }^{4}$ Puslitbang Kehidupan Beragama, Kompilasi Kebijakan dan Peraturan Perundang-undangan Kerukunan Umat Beragama, (Jakarta: Balitbang \& Litbang \& Diklat Puslitbang Kehidupan Keagamaan Depag RI, 2008), h. 19.

${ }^{5}$ Kantor Kementerian Agama, Panduan Model Kurikulum PAI Berbasis Multikultur SMP, (Dirjen Pendidikan Islam pada Sekolah, 2000), h. 20. 
E-ISSN : 2580-7056, ISSN : 2580-7064

Pascasarjana IAIN Palangka Raya

dipegang seorang muslim. Sebagaimana Yusuf al-Qaradhawi mengatakan bahwa toleransi dalam Islam dibangun atas landasan pokok, antara lain: ${ }^{6}$

1. Prinsip kemuliaan manusia betapapun beragamnya, (Q.S. al-Isra'/17:70).

2. Keyakinan bahwa perbedaan adalah keniscayaan dan kehendak Allah, (Q.S. Yunus/10:99).

3. Meyakini bahwa nonmuslim tidak bertanggung jawab terhadap jalan hidup umat muslim, (Q.S. al-Kahfi/18:29).

4. Berpegang pada prinsip keadilan, (Q.S. al-Maidah/5:8).

Pendapat di atas mengisyaratkan jika toleransi yang diajarkan Islam memiliki batasan sebagai prinsip dasar dalam bersikap universal, merujuk pada sumber ajaran agama sebagai tolok ukur. Berbeda jika dibandingkan dalam hal kesetaraan, perbedaan kemanusiaan, merujuk pada tolok ukur fisik dan hal-hal keduniawiaan. Sebagaimana diabadikan dalam al-Quran, antara lain:

1. Menolong kepada siapapun tanpa memilah orang miskin, sakit, bahkan berbeda agama, (HR. Bukhari nomor 2363 dan HR. Muslim nomor 2244).

2. Menjalin kekeluargaan pada nonmuslim, termasuk pada orang tua sendiri yang berbeda keyakinan, (Q.S. Luqman/31: 15), dan (Q.S. al-Mumtahanah/60: 8).

3. Kebolehan saling memberi hadiah pada nonmuslim, (H.R. Bukhari nomor 2619).

4. Berprinsip tegas dalam areal i'tiqadi, (Q. S. Al-Kafirun/109: 6).

Toleransi juga masuk dalam ranah religious culture secara universal, merupakan seperangkat keyakinan dan simbol atau nilai nilai yang diambil darinya, yang berhubungan dengan perbedaan antar realitas empiris dengan realitas transenden dan supra-emperis: soal-soal transendental berada di wilayah emperis. ${ }^{7}$ Religious culture di lembaga pendidikan seperti sekolah, sudah pasti terjadi interaksi yang

\footnotetext{
${ }^{6}$ Yusuf al-Qaradhawi, Fatâwâ M u'âshirah, (Manshurah: Dar al-Wafa', 1994), Cet. ke-3. Jilid ke-2. h. 667.

${ }^{7}$ William Outhwaite (ed), Kamus Lengkap Pemikiran Sosial Modern, (Jakarta: Kencana, 2008), edisi ke dua, cet.1, h. 732 .
} 
intens antar warga sekolah, baik itu kepala sekolah, pendidik, tata usaha, juga siswa. Terjadi hubungan yang saling mempengaruhi antara satu dengan yang lain, bisa berupa pengaruh positif juga pengaruh negatif, juga terdapat transfer budaya keberagamaan atau religious culture.

Pedoman yang tuntun Departemen Pendidikan Nasional dalam menciptakan religious culture antara lain dengan cara: melaksanakan ibadah bersama di sekolah sesuai dengan agama masing-masing penganutnya serta tidak mengganggu pemeluk agama lain; melaksanakan dan mengikuti kegiatan bersama yang dilaksanakan di sekolah sesuai dengan tuntunan agama masing-masing penganutnya, seperti memperingati hari besar keagamaan; secara arif dan bijaksana mengingatkan bagi yang lalai melaksanakan ibadah; menegur dan mencegah bagi yang melanggar hukum agama atau tatakrama dan tata tertib sekolah. ${ }^{8}$

Implementasi toleransi beragama di sekolah merupakan gambaran fenomena dan realitas budaya, berarti yang menjadi subyeknya adalah manusia itu sendiri. Walaupun dalam konsepnya agama itu datang dari Tuhan, tetapi makna dan implementasinya akan terwujud ketika agama itu diyakini, dipahami, dihayati, dan dipraktikkan oleh pemeluk agama dalam realitas budaya. Artinya, ketika agama diwahyukan kepada manusia, maka ia sudah terlibat dalam proses kompromi dan tawar-menawar dengan norma-norma budaya yang melembaga dalam kehidupan manusia". 9

Kepala sekolah yang berfungsi sebagai pimpinan di sekolah, dituntut kemampuannya dalam teknis pendidikan, manajerial dan interaksi dan hubungan sosial, termasuk menjaga agar toleransi di sekolah kondusif, tentu dengan memberdayakan kelebihan dan solutif terhadap kelemahan, karena maju mundurnya

\footnotetext{
${ }^{8}$ Muhaimin, Rekonstruksi Pendidikan dari Paradigma Pengembangan, Manajemen Kelembagaan, Kurikulum Hingga Strategi Pembelajaran, (Jakarta: PT. Grafindo Persada, 2009), h. 323.

${ }^{9}$ Komarudin Hidayat, Tragedi Raja Midas, Moralitas Agama dan Krisis Modernisme, (Jakarta, Paramadina: 1998), h. 4.
} 
sebuah sekolah sangat dipengaruhi oleh pimpinannya, sebagai orang pertama disekolah yang membawa pada tujuan untuk memanusiakan manusia, menjadi manusia yang ideal sesuai dengan tujuan pendidikan, sebagaimana termaktub dalam UUSPN. ${ }^{10}$

\section{Hasil Penelitian dan Analsis}

Pendidik di SMP Negeri 2 Arut Selatan sebanyak 41 orang, laki-laki 14 orang dan perempuan 26 orang, semua berstatus PNS dengan kualifikasi pendidikan minimal S-1 dan latar belakang pendidikan yang berbeda-beda. Ragam agama yang dianut tidak berpengaruh negatif dalam pergaulan. Prosentasi penganut agama guru dapat dilihat pada gambar berikut:

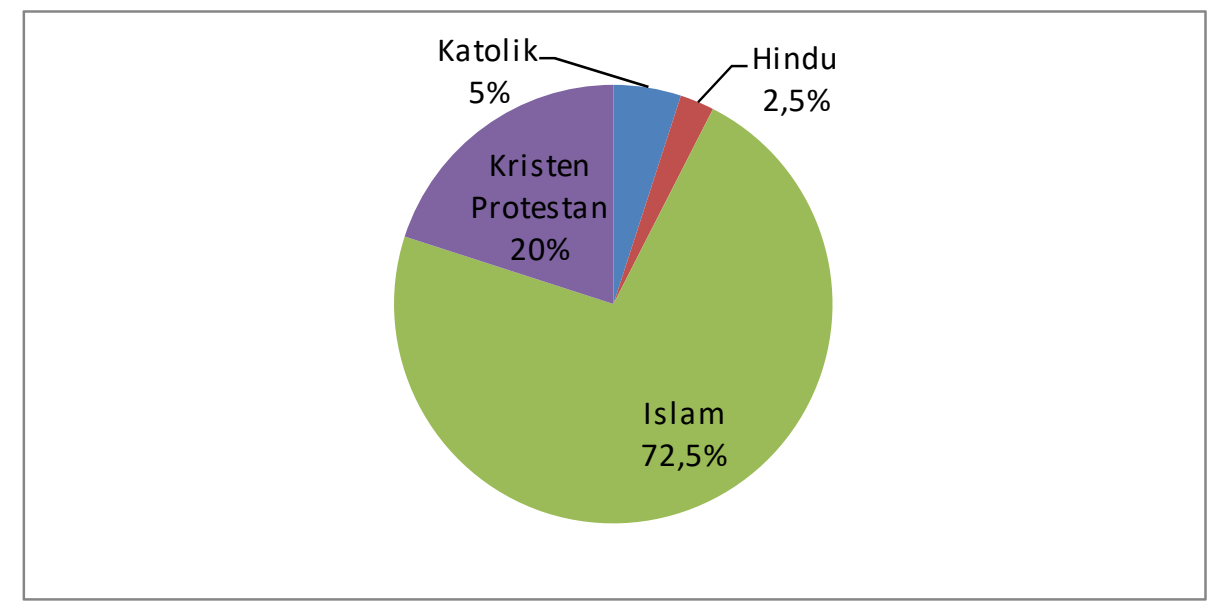

Gambar 1. Prosentasi penganut agama guru

Gambar 1 di atas menggambarkan jika Islam merupakan agama yang penganutnya mayoritas bagi guru di SMP Negeri 2 Arut Selatan, yaitu 29 orang beragama Islam atau $72 \%$. Selanjutnya Kristen Protestan 8 orang atau 20\%. Kristen Katolik pada urutan ketiga yaitu 2 orang atau 5\%. Kemudian yang beragama Hindu 1

${ }^{10}$ Kamrani Buseri, Reinventing Pendidikan Islam: Menggagas Kembali Pendidikan Islam Yang Lebih Baik, (Banjarmasin: Antasari Press, 2010), h. 46-48. 
orang atau 2,5\%. Faktanya, penganut agama guru-guru SMP Negeri 2 Arut Selatan bersifat heterogen dalam menganut agama. Berbeda dengan penganut agama tata usaha semuanya beragama Islam.

Artinya, secara faktual warga SMP Negeri 2 Arut Selatan sudah mendasarkan diri mereka pada nilai-nilai agama yang menjadi keyakinan masing-masing pemeluk agama terlepas dari mayoritas dan minoritas penganut agama dimaksud. Semua warga sekolah yang mengabdi di SMP Negeri 2 Arut Selatan mengaku jika dalam kesehariannya melakukan hubungan yang wajar dan tidak pernah merasa ada masalah, justru ada kenikmatan tersendiri dalam menjalankan tugas, toleransi beragama yang dijalankan selama selama sekolah ini beroperasi, sangat mendukung terhadap penciptaan religious culture.

Kepala sekolah pertama sekaligus sebagai pendiri yang berhasil diwawancarai menuturkan jika kehidupan beragama sudah baik sejak awal sekolah berdiri, diadakan kajian, juga lomba-lomba pada saat hari besar keagamaan, setiap bulan ada pengajian rutin bagi yang beragama Islam. Demikian juga bagi agama lain pada saat awal berdiri yang ada penganut agama Kristen Protestan dan agama Kristen Katolik, melakukan kebaktian ke gereja masing-masing.

Pendapat yang sama disampaikan oleh guru perempuan yang bertugas sejak tahun kedua sekolah beroperasi sampai sekarang, sangat merasakan kedamaian dalam bekerjasama dengan teman-teman yang muslim juga dengan yang nonmuslim, demikian juga dengan perlakuan kepala sekolah bahkan sampai kepada siswanya, misalnya melaksanakan kegiatan kebaktian perayaan natal, tidak pernah mempersulit dan selalu didukung, teman-teman yang beragama Islam juga ikut pada acara makanmakan selesai kebaktian jika memang diundang oleh panitia. Memang tidak selalu melibatkan semua pemeluk agama jika ada acara keagamaan di sekolah, karena disesuaikan dengan bentuk acara, waktu, juga pertimbangan lainnya. 
Agama Kristen Katolik dan agama Kristen Protestan lebih sering bersamasama dalam memperingati hari besar keagamaan, mereka berbagi peran dalam mengisi acara, meski terkadang ada sedikit perbedaan dalam teknis peribadan, tetapi mereka mencari persamaannya demi sebuah kebersamaan, sehingga bisa mengadakan acara bersama-sama, selain alasan karena jumlah jamaahnya yang masih sedikit.

Wakil kepala sekolah urusan hubungan masyarakat juga menyatakan hal yang sama, bagaimana suasana religious yang dirasakan di sekolah, berharap agar suasana keberagamaan sekolah harus dipertahankan karena sudah sangat baik, rasa saling menghormati yang tinggi. Bahkan mengaku meski terkadang tidak diundang, misalnya kegiatan buka puasa bersama bersama siswa di sekolah, tidak sungkansungkan permisi untuk ikut serta. Seperti ini terjadi karena adanya rasa kekeluargaan dan saling berprasangka baik.

Guru yang lain lebih ektrim lagi dengan pernyataannya, bahwa susah mencari sekolah seperti SMP Negeri 2 Arut Selatan dalam hal penerapan toleransi beragama, guru tersebut meyakini jika yang lain juga merasakan hal yang sama, selain karena pernah mengajar di sekolah lain, juga mendengar cerita dari empat saudaranya juga sebagai guru yang bertugas di tempat yang berbeda-beda, memang di SMP Negeri 2 Arut Selatan yang kelihatan dan terasa sekali kerukunannya. Kenyamanan ini bisa bertahan dengan baik karena masing-masing menjaga dan mengerti batasan-batasan yang boleh dan yang tidak boleh dalam pergaulan.

Sungguhpun demikian ada sebagian guru dan pegawai sekolah yang tidak mau ikut pada jamuan makan setelah acara kebaktian jika ada acara hari besar keagamaan di sekolah, tetapi semua pihak di sekolah memaklumi jika itu adalah prinsip bagi masing-masing pemeluk agama. Ditegaskan oleh guru Pendidikan Agama Islam yang sering menjadi panitia dalam kegiatan PHBI (Peringatan Hari Besar Islam), bahwa kegiatan-kegiatan yang tujuannya mengutamakan kebersamaan bersama, biasanya selalu mengundang teman-teman nonmuslim pada acara keislaman, tetapi apabila 
kegiatannya dilaksanakan di rumah ibadah, maka yang diundangpun khusus muslim saja, atau kegiatan yang tujuannya untuk mengkaji ajaran Islam secara khusus, juga tidak mengundang agama selain Islam. Ini semua dilakukan bukan karena meniadakan toleransi, tetapi justru menjaga batasan toleransi.

Penulis mengikuti kegiatan peringatan maulid Nabi Muhammad SAW., yang dilaksanakan pada hari Selasa tanggal 15 Pebruari 2011 mulai pukul 07.00 sampai selesai, bertempat di halaman sekolah, menggunakan tenda dan panggung acara, sama sekali tidak menyaksikan guru dan pewai sekolah nonmuslim berhadir, ternyata mereka memang tidak diundang. Mereka tidak diundang karena acaranya melibatkan lomba-lomba anak SD yang ada di kota Pangkalan Bun, artinya karena melibatkan pihak luar sekolah dalam acara tersebut, sehingga pesertanya khusus yang muslim saja. Selesai acara, ada panitia yang menitipkan menitipkan snack kotak yang jumlahnya sengaja dilebihkan oleh panitia karena memang diperuntukkan bagi mereka yang nonmuslim.

Artinya, budaya perayaan hari besar keagamaan di sekolah tersebut melibatkan personil agama lain sebagai undangan, bukan sebagai panitia. Terkecuali ada beberapa personil sekolah yang secara informal karena kedekatan berteman membantu secara teknis. Faktanya tidak pernah ada masalah karena dianggap mereka masih dalam batas-batas yang lazim. Mereka lebih memilih cara-cara yang sifatnya preventif. Tidak hanya dalam masalah toleransi beragama saja, tetapi juga dalam semua hal yang berhubungan dengan kepemimpinan di sekolah.

Hidup dalam kebersamaan bukan berarti harus sama, setiap ada hal-hal yang mengarah pada intoleransi, masing-masing pihak mencari cara untuk mengecilkannya/ meniadakannya, hingga tidak menjadi masalah. Sudah di ingatkan oleh Ahmadi Hasan dalam bukunya Adad Badamai: Interaksi Hukum Islam dan Hukum Adat pada Masyarakat Banjar, bahwa "meskipun nampaknya kondisi sosial 
E-ISSN : 2580-7056, ISSN : 2580-7064

Pascasarjana IAIN Palangka Raya

dan keagamaan cukup tenang, akan tetapi diasumsikan bahwa kondisi yang tenang tersebut bukan jaminan tidak akan muncul konflik."

Toleransi lain yang diperlihatkan oleh sekolah ini dalam bentuk saling berkunjung pada saat muslim merayakan Idul Fitri, nonmuslim merayakan Natal dan Nyepi. Ketiga hari besar ini selalu dirayakan oleh guru dan pegawai penganut agama di SMP Negeri 2 Arut Selatan di rumahnya masing-masing, sebagaimana pernyataan berikut:

"kami sekeluarga menata rumah setiap tahun, termasuk menyiapkan makanan alakadarnya untuk menjamu teman kerabat dan siswa berkunjung ke rumah pada saat hari raya Idul Fitri, terlebih lagi kami memang memiliki keluarga besar di Pangkalan Bun, juga ada teman-teman nonmuslim biasanya juga datang bersama keluarganya, bagi kami ini sebuah penghormatan mereka, kami pun bisa memanfaatkannya untuk meminta maaf. Kami pun biasa berkunjung ke tempat mareka apabila hari raya Natal dan Nyepi, biasanya saya juga bersama keluarga untuk meminta maaf dan mengucapkan selamat hari raya natal atau selamat hari raya nyepi".

Guru di atas menganggap jika saling berkunjung pada saat agama lain merayakan hari raya, merupakan hal biasa dan dianggap sebagai suatu penghormatan dan kesempatan saling meminta maaf, termasuk mengucapkan selamat Hari Natal atau selamat hari raya Nyepi bagi yang merayakannya. Ada beberapa perbedaan sikap yang ditunjukkan guru muslim lainnya dalam masalah ini.

Misalnya guru yang mengajar biologi, tidak pernah berkunjung pada saat perayan hari Natal, tetapi biasa dan bisa berkunjung pada hari-hari selainnya, seperti pada saat ada kematian, kelahiran, pernikahan atau ada keperluan lain. Guru tersebut berpendapat jika menjaga pertemanan dengan berkunjung ke rumah tidak harus di hari raya Natal, dan kalau berkunjung saat hari raya Natal berarti ikut juga merayakannya, apabila terlibat ikut merayakan berarti setuju dengan yang dilakukan. Juga tidak pernah mengucapkan kata "selamat", karena agama Islam memang

${ }^{11}$ Ahmadi Hasan, Adad Badamai: Interaksi Hukum Islam dan Huklum Adat pada Masyarakat Banjar. (Banjarmasin: Antasari Press, 2007), h. 5. 
membatasi pemberian ucapan tersebut kepada nonmuslim, bisa saja mengatakan hal yang lain untuk urusan duniawi. "Maaf bukan berarti saya tidak toleransi tetapi ini adalah gaya saya bertoleransi", demikian penegasan guru tersebut.

Toleransi juga ditunjukkan dalam hal "makanan dan minuman". Semua yang muslim sepakat untuk lebih berhati-hati, dan ini juga sudah mengerti oleh yang nonmuslim di sekolah, sehingga berupaya untuk menghargai dan mengondisikannya. Seorang tata usaha yang muallaf mengaku jika sebelum muallaf pun sudah mengetahui bahwa ada makanan dan minuman yang haram dikonsumsi oleh pemeluk agama Islam seperti memakan anjing dan babi, karena dilingkungan tempat tinggalnya waktu kecil sudah bergaul dengan keluarga muslim, juga sudah ada beberapa keluarga yang muslim. Semenjak menjadi muslim, keluarganya pun menghormati dengan tidak menyuguhkan makanan dan minuman yang dilarang dalam Islam.

Hampir sama dengan pernyataan guru sejarah yang nonmuslim, beliau pernah bertanya kepada salah seorang guru muslim di sekolah tentang makanan dan minuman yang tidak boleh dikonsumsi orang Islam, pertanyaan itu terlontar karena mau mengundang pada acara syukuran anak kedua lulus sekolah dan yang pertama lulus tes pegawai negeri. Guru sejarah ini semakin memahami setelah dijelaskan bahwa bekasnya pun tidak boleh kecuali sudah disucikan menurut ketentuan Islam. Sebagai bentuk toleransinya, meminta orang Islam bahkan lebih sering teman satu sekolah untuk memasaknya, supaya teman-teman satu sekolah yang hadir merasa yakin keamanan dan kehalalannya.

Guru Pendidikan Agama Islam di SMP Negeri 2 Arut Selatan menguatkan pendapat di atas, jika yang nonmuslim sangat memahami dengan makanan dan minuman yang seharusnya dikonsumsi dan tidak dikonsumsi umat Islam. Sungguhpun demikian, guru ini mengaku tetap ada keraguan jika makan atau minum di salah seorang guru yang nonmuslim, meskipun sudah dikatakan jika yang 
memasak adalah orang Islam. Alasannya karena memelihara anjing di rumahnya dan sudah pernah ia saksikan, suatu waktu anjing tersebut berkeliaran di dalam rumah dan menjilat-jilat sisa makanan di tempat yang belum dicuci. Fakta ini menjadikannya tetap syak dengan kesuciannya, sehingga menahan diri untuk tidak menikmatinya dan memilih makanan atau minuman kemasan siap saji.

Berbeda dengan seorang guru lain, mengaku berteman akrab dengan yang nonmuslim dan sering berkunjung ke rumahnya tidak hanya pada acara natal, bahkan sering makan dan minum karena sudah seperti saudara sendiri, selain itu juga karena tahu jika teman akrabnya memang tidak pernah memasak makanan dan minuman yang tidak boleh dimakan orang Islam, ini yang jadi alasan sesungguhnya sehingga merasa yakin dan aman menikmatinya.

Ada juga guru nonmuslim lain berkiat hampir sama dengan yang diungkapkan oleh guru di atas, bahkan dia yang duluan mengatakan kalau di rumahnya aman untuk makan dan minum bagi orang Islam, mereka hanya makan anjing dan babi di tempat keluarga, karena orang yang membantu di rumahnya beragamanya Islam, jadi harus tahu diri dalam masalah itu, dan mereka juga membolehkan kalau yang membantu di rumahnya melaksanakan shalat atau belajar mengaji ke rumah tetangga atau ke masjid.

Kedua guru di atas menunjukkan rasa saling menghormati terhadap yang boleh dan yang tidak boleh untuk dikonsumsi muslim, bahkan memberi kesempatan kepada orang lain untuk beribadah menurut masing-masing penganut agama, saling berkunjung pada saat perayaan natal juga merupakan hal biasa mereka lakukan. Berikut ada juga guru nonmuslim yang mengaku jika keluarga mereka sering meminta tolong kepada teman di sekolah untuk membuatkan makanan untuk disajikan saat perayaan natal maupun acara lainnya, dengan maksud supaya temanteman yang muslim tidak merasa ragu dan merasa aman. Guru tersebut meyakini jika semua guru dan tata usaha sekolah sudah tau dengan kebiasaannya. 
Hari Sabtu tanggal 26 Pebruari 2011 diadakan gotong royong di sekolah untuk persiapan pemeriksaan dari tim kabupaten, yaitu dari Kantor Badan Lingkungan Hidup yang akan melakukan peninjauan ke sekolah. Sebagai upaya mendapatkan kembali piala Adipura V bagi Kabupaten Kotawaringin Barat. Ada guru Bahasa Inggris yang punya ide untuk makan-makan di sekolah seperti biasanya. Ide ini direspons positif oleh guru yang lain, masing-masing menawarkan diri untuk membawa ini dan itu. Tiba-tiba ada seorang guru yang menolak dan mengatakan untuk membawa buah saja, karena di rumahnya baru saja memasak anjing. Pernyataan yang keluar dari seorang guru nonmuslim tersebut sebagai bentuk paham dan melaksanakan toleransi antar agama.

Penulis juga mendapati fakta pada saat ujian praktik siswa kelas IX, materinya menyajikan hidangan, mulai tanggal 14-19 Maret 2011, penulis melihat ada seorang guru laki-laki yang tidak mau mencicipi hidangan, meski sudah beberapa kali disilahkan oleh wali kelas yang siswa di kelasnya terdiri dari berbagai macam agama. Wali kelas tersebut kembali menyilahkan dan menegaskan bahwa yang membuat makanan adalah orang tua dari si "A". Orang tua yang disebut sudah sangat dikenal dan tahu betul jika beragama Islam dan mengatakan "tidak ada satu pun makanan yang dibuat di rumah yang beragama Kristen”. Guru yang beragama Islam tersebut mendekat dan menikmati hidangan yang ada. Fakta ini menunjukkan jika tolerasi beragama di SMP Negeri 2 Arut Selatan benar-benar diimplementasikan dalam kehidupan sekolah.

Beberapa fakta di atas, diketahui jika guru dan tata usaha di SMP Negeri 2 Arut Selatan, melaksanakan toleransi antar umat beragama dengan cara yang variatif dan fleksibel. Seperti saling menghormati dalam merayakan hari besar keagamaan yang dilakukan masing-masing agama dan sikap yang ditunjukkan oleh masingmasing penganut agama; menghormati batasan makan dan munum menurut agama tertentu, bagi yang nonmuslim lebih bersikap preventif dengan memberitahukan 
terlebih dulu sumber dan cara membuat, sehingga yang muslim tidak merasa ragu atau syak.

Fakta di atas juga menunjukkan jika semua yang muslim lebih bersikap hatihati dan selektif dalam masalah makanan dan minuman halal/ haram. Sikap inipun sudah sangat dipahami oleh nonmuslim, sehingga sikap saling menghargai dan mengerti selalu dikedepankan. Dalam hal ini mereka sudah mempraktikkan firman Allah,

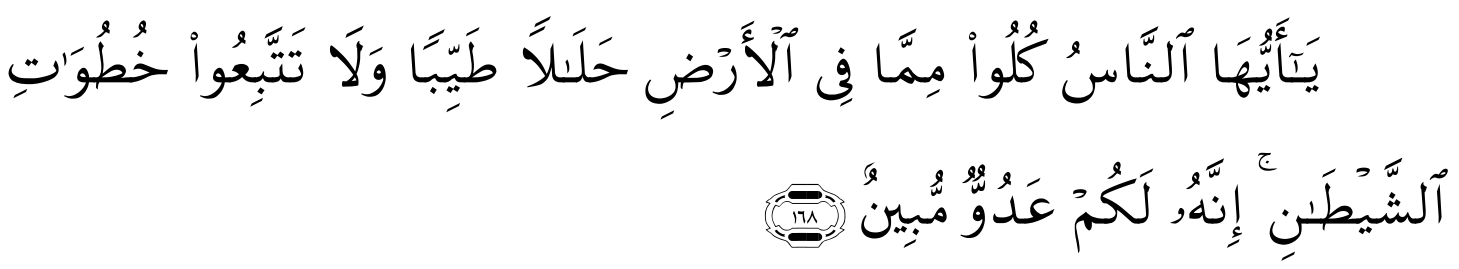

Hai sekalian manusia, makanlah yang halal lagi baik dari apa yang terdapat di bumi, dan janganlah kamu mengikuti langkah-langkah syaitan; karena Sesungguhnya syaitan itu adalah musuh yang nyata bagimu. (Q.S. al-Baqarah/2: 168)

Makanan halal adalah makanan yang diperbolehkan menurut ketentuan hukum Islam. Halal dimaksud menyangkut: halal zatnya, seperti beras, buah-buahan, lauk pauk dan lain-lain. Halal hakikatnya, yaitu makanan yang diperoleh atau diolah dengan cara yang benar menurut Islam. Makanan haram adalah kebalikannya, yaitu haram zatnya, seperti anjing, babi, darah, termasuk bangkai selain ikan dan belalang, dan lain-lain. Haram hakikatnya, yaitu makanan yang diperoleh atau diolah tidak sesuai dengan ketentuan ajaran Islam, misalnya hewan halal yang disembelih tidak menyebut nama Allah, makanan dari hasil mencuri/korupsi, dan lain-lain.

Pada ayat di atas, Allah swt tidak hanya tegas menyuruh untuk memakan makanan halal saja, tetapi juga memakan makanan dari yang baik-baik. Terdapat juga firman Allah yang lain, 


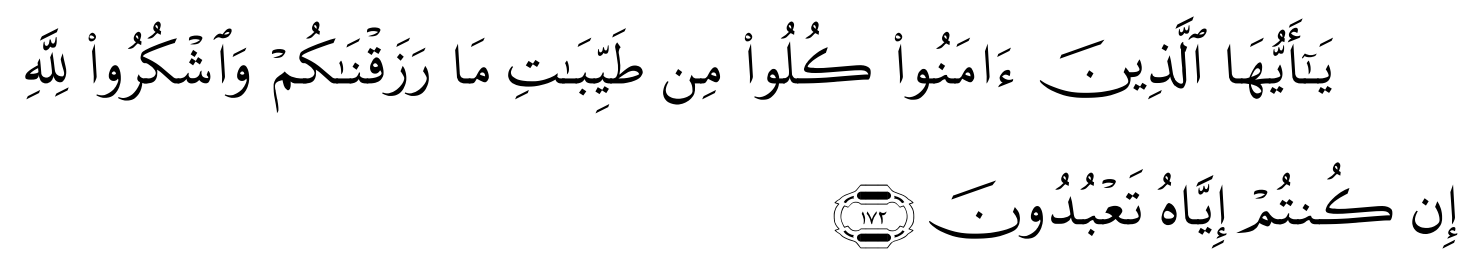

Hai orang-orang yang beriman, makanlah di antara rezki yang baik-baik yang Kami berikan kepadamu dan bersyukurlah kepada Allah, jika benar-benar kepada-Nya kamu menyembah. (Q.S. al-Baqarah/2: 172)

Allah swt. mengulang penegasan-Nya kembali untuk memakan makanan yang baik sebagaimana ayat terdahulu. Makanan yang baik adalah makanan yang dapat dipertimbangkan secara akal dan menurut ukuran dari segi kesehatan, artinya kriteria makanan yang baik lebih bersifat kondisional juga situasional dari orang yang bersangkutan, hal ini dijelaskan dalam hadis berikut.

H.R. Bukhari dan Muslim "Dari Abu Abdillah Nu'man bin Basyir r.a, "Saya mendengar Rasulullah saw bersabda, 'sesungguhnya yang halal itu jelas dan yang haram itu jelas. Diantara keduanya terdapat perkara-perkara yang syubhat (samar-samar) yang tidak diketahui oleh orang banyak. Maka barang siapa yang takut terhadap syubhat, berarti dia telah menyelamatkan agama dan kehormatannya. Dan barang siapa yang terjerumus dalam perkara syubhat, maka akan terjerumus dalam perkara yang diharamkan. Sebagaimana gembala yang mengembalakan hewan gembalaannya di sekitar (ladang) yang dilarang untuk memasukinya. Ketahuilah bahwa setiap raja memiliki larangan dan larangan Allah adalah apa yang Dia haramkan. Ketahuilah bahwa dalam diri ini terdapat segumpal daging, jika dia baik maka baiklah seluruh tubuh ini, dan jika dia buruk, maka buruklah seluruh tubuh. Ketahulah bahwa dia adalah hati."

Guru dan tata usaha yang merasa syak/ragu terhadap kehalalan yang dikonsumsi, merupakan penerapan keyakinan yang bersumber dari agama sebagaimana bunyi hadis di atas. Tentu memiliki pengaruh yang kuat terhadap tingkah laku individu karena merupakan puncak sumber nilai tertinggi dan lebih bersifat absolut. ${ }^{12}$ Sudah barang tentu tidak dapat dilepaskan dari aktivitas seorang guru dan pegawai tata usaha yang merupakan diri individu, sebagai abdi negara yang

\footnotetext{
${ }^{12}$ Kamrani Buseri, Reinventing Pendidikan Islam..., h. 33.
} 
bertugas dilembaga pendidikan/sekolah juga sebagai anggota masyarakat, dan seharusnya untuk melekatkan nilai religious culture islami di setiap lini kehidupan.

Selanjutnya, pada hari pertama diadakan try out siswa kelas IX, pagi sebelum bel otomatis sekolah berbunyi, datang bapak Wayan Sweda S. Pd. AH. Tiba-tiba ada panitia yang meminta maaf karena tidak memasukan dalam jadual pengawas pada hari pertama dan kedua, karena dikira masih izin untuk merayakan hari Raya Nyepi. Fakta ini menunjukkan bahwa toleransi mereka juga dalam bentuk berempati dengan memberi kesempatan pada agama lain untuk merayakan hari besar agama mereka masing-masing di luar sekolah, tanpa terkecuali pada pemeluk agama yang jumlahnya minoritas.

Ada perberbedaan dengan keyakinan dan sikap seorang guru BP/BK, mengaku berteman dengan semua yang ada di sekolah, dan melaksanakan program sekolah bersama-sama serta bercengkrama bersama, tetapi tetap mencari teman akrab yang seagama yaitu Islam. Teman akrab yang dimaksudkan, akan dijadikan tempat untuk mencurahkan perasaan. Tetapi juga tidak menutup diri, karena selalu berkunjung pada saat teman nonmuslim merayakan hari Natal, meski tidak pernah mengucapkan selamat natal atau semacamnya. Tidak mengucapkan "selamat natal" merupakan hal prinsip yang dia pegang.

Hampir sama dengan guru Pendidikan Agama Islam, yang berprinsif bahwa bergaul secara wajar dan ini merupakan sebuah keniscayaan dalam hidup dan mengabdi di lembaga pendidikan/sekolah umum, seperti berkunjung ke rumah yang nonmuslim, tetapi tidak pernah tepat pada hari perayaan natal serta tidak mau mengucapkan selamat natal/selamat nyepi. Memilih terlebih dulu mengucapkan kata maaf atas salah dan khilaf selama bergaul. Ini satu prinsip dalam menjaga toleransi, karena seandainya mengucapkan "selamat", berarti menyetujui terhadap apa yang mereka diyakini, jadi kehadirannya berkunjung pada minggu setelah atau sebelum natal atau pada hari yang lain di luar perayaan hari besar keagamaan nonmuslim, 
untuk menjaga kebersamaan pertemanan saja. Demikian halnya jika diundang sebuah acara kebaktian, meskipun yang muslim hanya berada di ruang kantor jika di sekolah, sedangkan acara mereka berada di ruang khusus, juga tidak mau datang karena menurutnya sudah berada pada kapling melaksanakan ibadah ritual, jadi sudah harus bersikap lakum dịnukum waliyadịn.

Kenyataan di atas menggambarkan jika semua guru dan tata usaha menganggap hubungan kerja dengan semua penganut agama di sekolah, sebagai suatu hubungan yang wajar dan tidak pernah ada kendala. Masing-masing memahami dan memegang komitmen dengan batasan-batasan yang lazim dalam agama dan prinsip yang dipegang oleh masing-masing penganut agama. Misalnya saja dalam peringatan hari natal, ada baiknya jika memperhatikan pendapat Isre, "dalam hal penyelenggaraan perayaan hari besar keagamaan yang kurang mempertimbangkan kondisi dan situasi serta lokasi di mana perayaan tersebut diselenggarakan dapat menyebabkan timbulnya kerawanan di bidang kerukunan hidup umat beragama". ${ }^{13}$ Pihak sekolah sudah mengantisipasinya agar tetap bertoleransi pada batas-batas yang lazim untuk menjalankan dan memelihara serta mempertahan toleransi yang sudah dibanggakan warga sekolah.

Sikap dan pernyataan yang ditunjukkan oleh guru dan tata usaha sekolah sangat jelas, jika semuanya saling menghormati. Guru yang nonmuslim mengerti betul terhadap hal-hal yang boleh dan tidak boleh bagi Islam, seperti batasan ikut kegiatan keagamaan sampai pada masalah makan dan minum. Guru dan tata usaha yang beragama Islam lebih selektif menjaga toleransi beragama karena memang ada aturan-aturan syar'i yang membatasi, mulai dari pergaulan yaitu batasan untuk ikut atau tidak ikut pada acara keagamaan, termasuk bertutur kata yaitu pengucapan kata "selamat" sampai pada masalah memilih atau mengonsumsi makan dan minum.

\footnotetext{
${ }^{13}$ Isre, Moh. Soleh (ed.), Konflik Etnis Religius Indonesia Kontemporer, (Jakarta: Proyek Peningkatan Pengkajian Kerukunan Hidup Umat Beragama, Puslitbang Kehidupan Beragama, Badan Litbang Agama dan Diklat Keagamaan Departemen Agama RI, 2003), h. 270.
} 
Dengan demikian, ada beberapa sikap toleransi dalam berkunjung pada saat perayaan natal bagi guru dan tata usaha yang beragama Islam, yaitu: 1) ada yang saling berkunjung; 2) ada yang berkunjung tetapi bukan pada saat perayaan natal;, dan 3) ada yang tidak. Perbedaan itu terjadi hanya karena berbeda dalam memberikan persepsi dan batasan memaknai kata "ibadah ritual". Guru dan tata usaha muslim semuanya sepakat jika tidak boleh ikut dalam ranah ibadah ritual agama lain, ini sesuai dengan firman Allah swt.,

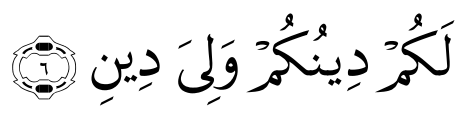

Untukmu agamamu, dan untukkulah, agamaku. (Q.S. al-Kafirun/109: 6)

Agama Islam sangat ketat dalam megatur toleransi yang berhubungan dengan ibadah mahdhah, dan memang memberikan kelonggaran dalam masalah hubungan sosial/muamalah, karena untuk lebih memungkinkan terjadinya adaptasi yang flesibel dalam berbagai situasi dan kondisi penganut Islam selama berpegang pada prinsip lakum dịnukum waliyadịn tersebut.

Berkenaan dengan pengucapan kata "selamat natal", Muhammad Quraisy Shihab telah menafsirkan firman Allah yang berkenaan dengan kisah natal dalam alQuran,

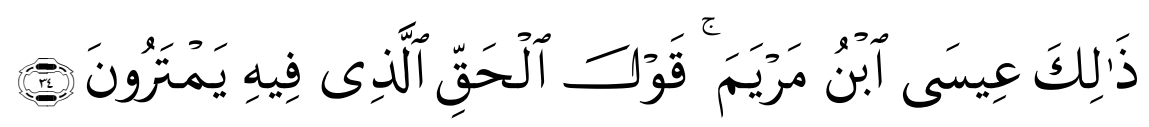

Itulah Isa putera Maryam, yang mengatakan perkataan yang benar, yang mereka berbantah-bantahan tentang kebenarannya. (Q.S. Maryam/19: 34)

Penjelasan Muhammad Quraisy Shihab terhadap ayat di atas, bahwasanya tidaklah salah mengucapkan kata selamat natal, selama aqidah yang muslim dapat terjaga dan dipegang teguh. Alasan ini yang dapat dijadikan sebagai pembenaran bagi seorang muslim yang mengucapkan selamat atau menghadiri upacara natal yang 
bukan ritual ibadah nonmuslim. ${ }^{14}$ Alasan ini sesuai dengan batasan yang dimaksudkan oleh guru yang menganggap hanya sekedar berkunjung atau menghadiri undangan natal yang merupakan perbuatan kemanusiaan saja. Guru yang melakukan menganggap perbuatan tersebut ditafsirkan tidak sama dengan ritual keagamaan. Ajaran Islam, yang menyangkut ranah kehidupan sosial dengan semua orang memang lebih longgar dibandingkan masalah lain seperti masalah aqidah dan tauhid, sehingga bisa saja terjadi berbagai macam persepsi. Pada saat situasi dan kondisi yang mengitari seseorang/kelompok orang berbeda dengan orang/kelompok lain, maka bisa jadi berbeda juga persepsi terhadap implementasinya dalam masalah toleransi semacam ini.

Mayoritasnya jumlah pemeluk agama Islam di SMP Negeri 2 Arut Selatan sejak awal berdiri sampai sekarang, mampu menunjukkan sebagai agama yang mengayom sebagaimana yang dirasakan/dinyatakan oleh semua yang nonmuslim. Toleransi seperti ini secara umum telah berlaku di seluruh Indonesia. Sebagaimana yang pernah diungkapkan oleh Nurcholis Madjid bahwa Islam telah membuktikan kemampuannya secara meyakinkan dalam melaksanakan toleransi dan pluralisme secara unik dalam sejarah agama-agama, di mana agama Islam merupakan anutan mayoritas, agama-agama lain tidak mengalami kesulitan berarti. ${ }^{15}$

Selain penganut agama Islam mampu sebagai pengayom dan bersikap sebagai pamong yang ngemong golongan-golongan lainnya, juga telah mampu menunjukkan sikap terbuka, yang menjadikan penganut nonmuslim bisa tampil dengan rasa percaya diri di SMP Negeri 2 Arut Selatan. Hal ini karena memang dalam Islam sudah ada doktrin untuk menjalankan agama dan keagamaaan secara universal, "Islam memberi

\footnotetext{
${ }^{14}$ M. Quraisy Shihab, "Membumikan" Al-Quran: Fungsi dan Peran Wahyu Dalam Kehidupan Masyarakat, (Bandung: Mizan, 1992), Cet. II, h. 371.

${ }^{15}$ Nurcholis Madjid, Islam, Doktrin dan Peradaban: Sebuah Telaah Kritis Tentang Masalah Keimanan, Kemanusiaan, dan Kemoderenan, (Jakarta, Paramadina: 1995), h.7-8.
} 
landasan religius bagi para pemeluk untuk menerima keberadaan agama lain dan mengadakan hubungan baik bagi para pemeluknya". ${ }^{16}$

Penulis juga memperhatikan guru yang mendidik/mengajar, tidak jarang mereka mengungkapkan perkataan yang menghubungkan dengan nilai-nilai agama secara universal. Artinya penanaman nilai-nilai dari budaya toleransi disampaikan secara inverbalistik dan informalistik melalui tatap muka pada saat proses belajar mengajar, juga interaksi di luar kelas.

Penulis dalam hal ini tidak membahas secara dalam tentang pembelajaran agama terhadap kehidupan duniawi, karena muatan dari pendidikan agama itu sendiri sudah tegas menyatakannya, yang dituntut selanjutnya adalah "pembelajaran terpadu", yaitu bagaimana pendidikan agama menghubungkan nilai-nilainya terhadap pengetahuan umum dan sebaliknya. Penulis saksikan seorang guru Pendidikan Agama Islam yang membantu mengajar pelajaran Seni Budaya, pernah meluruskan pemaknaan/penerapan toleransi yang salah, seperti menemui kasus yang sedikit ekstrim, pernah menemui siswa muslim yang melukis dibukunya gambar salib, guru tersebut meluruskan/menegaskan bahwa Islam memang harus bertoleransi kepada semua umat manusia selain yang berkaitan dengan i'tiqadiyah (keyakinan/ketauhidan). Toleransi yang berkaitan dengan masalah muamalah diperbolehkan, sedangkan yang berkaitan dengan masalah i'tiqad sangat dilarang dan termasuk paling prinsip.

"Penerapannya dilapangan, pemahaman guru agama tentang konsep toleransi dan kerukunan beragama, diperoleh hasil bahwa guru agama sudah cukup paham tentang konsep toleransi dan kerukunan beragama. Di samping karena tingkat pendidikannya yang memadai, memiliki pengalaman mengajar di sekolah umum yang memiliki siswa yang nonmuslim. Menurutnya Islam membolehkan melaksanakan toleransi dan kerukunan beragama dan bahwa toleransi dan kerukunan berkaitan dengan hak azasi manusia yang tidak bisa dipaksakan oleh orang lain, karena merupakan keyakinan yang terpatri sudah di

${ }^{16}$ M. Ilham Maskhuri Hamdie, Pluralitas Agama Menuju Dialog Antar Agama; Talaah Dimensi Sufistik Pemikiran Nurcholis Madjid, (Banjarmasin: Antasari Pres, 2006), h. 15. 
dalam hati sebagaimana al-Quran menyebutkan "bagimu agamamu dan bagiku agamaku". ${ }^{17}$

Pendapat di atas menegaskan jika sikap yang ditunjukkan guru Pendidikan Agama Islam dengan meluruskan pola fikir siswa bahwa Islam membolehkan toleransi berkaitan dengan masalah muamalah dan perketat toleransi dalam masalah i'tiqadiyah. Ini bukan berarti intoleransi, justru sebagai acuan bagi yang beragama Islam dalam bertoleransi dengan nonmuslim. Meski demikian, juga pernah terjadi peristiwa yang hampir mengarah pada intoleransi, bahkan hampir mengarah pada ranah konflik di SMP Negeri 2 Arut Selatan.

Pertama, yaitu kasus seorang guru Pendidikan Agama Hindu yang pernah berbincang ringan dengan salah seorang guru muslim, materi yang diperpincangkan sampai pada masalah ajaran agama, akibatnya ada ketersinggungan yang dibuktikan dengan sempat terdengar suara bernada tinggi. Setelah itu, masing-masing merasa tidak enak karena keluar dari kebiasaan di sekolah yang menjunjung sikap preventif, akhirnya masing-masing meminta maaf. Kejadian itu membuat mereka sangat berhati-hati apabila berbincang mengenai ajaran agama. Menurut Isre, momentum itu biasanya hanya berbentuk pertengkaran kecil antara dua individu mengenai sesuatu yang amat remeh atau jauh dari akar konflik, tetapi berfungsi menjadi pembenar bagi dimulainya suatu konflik yang berskala besar. ${ }^{18}$

Kedua, pernah terjadi pembagian kitab Inzil kepada siswa yang beragama Islam. Penulis melihat pada buku tamu dan dokumen kronologis yang masih disimpan oleh salah seorang Guru Pendidikan Agama Islam, tertanggal 23 Agustus 2006, sekolah kedatangan tamu dua orang laki-laki dari salah satu yayasan berkantor pusat di Jakarta. Setelah menyampaikan maksud kedatangannya, diizinkan oleh kepala sekolah menemui siswa di kelas yang ada siswa nonmuslimnya ${ }^{19}$. Setelah

\footnotetext{
${ }^{17}$ M. Ilham Maskhuri Hamdie,. Pluralitas Agama..., h. 104-105.

${ }^{18}$ Isre, Moh. Soleh (ed.), Konflik Etnis... h. 5-6.

${ }^{19}$ Kelas VII A, VIIB, VIIIA, VIIIB IXA dan IXB.
} 
berkenalan serta memberi nasihat religius, kemudian meminta kepada siswa yang beragama Kristen Katolik dan Kristen Protestan untuk mengangkat tangan dan membagikan al-Kitab. Ternyata ada sebelas orang siswa muslim di kelas VIIIB yang kebagian. Padahal sudah diingatkan oleh guru matematika kebetulan beragama Kristen Protestan yang mengajar saat itu untuk tidak mempelajarinya, karena Islam sudah punya kitab suci sendiri yaitu al-Quran.

Esok harinya ada tiga orang tua yang menemui guru Pendidikan Agama Islam, menyatakan sikap tidak terima karena anaknya mendapat kitab Inzil, ini sebagai reaksi terhadap peristiwa pembagian kitab Inzil kepada siswa yang beragama Islam. Kepala sekolah meminta Guru Agama Kristen untuk menarik kitab tersebut dan harus meminta maaf kepada orang tua yang bersangkutan. Kepala sekolah dan wakil kepala sekolah serta guru-guru agama duduk satu meja, dipertemukan oleh kepala sekolah untuk mengevaluasi dan menegaskan agar tidak terjadi lagi kasus semacam itu. Meski sempat terjadi protes dari Guru Pendidikan Agama Islam yang menganggap sudah melanggar hukum karena "sudah menyebarkan agama pada orang yang sudah beragama dan sudah mengembala di kandang orang lain serta menyebarkan virus intoleransi”, demikian yang disampai Guru Pendidikan Agama Islam tersebut. Dengan kebijakan kepala sekolah pada saat itu, semua bisa memahami dan Guru Agama Kristen yang terlibat mengungkapkan penyesalannya dan berjanji untuk tidak terulang.

Terhadap kasus yang pertama, kedua guru saling menyadari jika sudah mengarah pada intoleransi, mereka berusaha menyelesaikan masalah tanpa melibatkan orang atau pihak ketiga. Terhadap kasus yang kedua, diselesaikan oleh kepala sekolah sebagai pihak/orang ketiga. Berkenaan dengan konflik semacam ini, terdapat berbagai strategi penyelesaiannya. Cara yang pertama, dapat dilakukan oleh kedua belah pihak secara kekeluargaan (rekonsiliasi), cara kedua dilakukan oleh kedua belah pihak dengan menggunakan jasa pihak ketiga sebagai perantara atau juru 
damai (mediasi), dan cara ketiga dilakukan secara paksa kepada kedua belah pihak oleh kekuasaan masyarakat atau kekuasaan negara (ligitimasi). ${ }^{20}$

"Penyebaran agama dari masing-masing kelompok agama itu sering disinyalir sebagai sumber ketegangan antara satu penganut agama dengan penganut agama yang lain. Dalam hal ini penyiaran agama baik secara lisan, melalui media cetak seperti brosur, pamflet, selebaran dan sebagainya, maupun media elektronika, serta media yang lain dapat menimbulkan kerawanan di bidang kerukunan hidup umat beragama, lebih-lebih ditujukan kepada orang yang sudah memeluk agama lain". ${ }^{21}$

Ungkapan di atas merupakan kenyataan yang ada di Indonesia sekaligus dapat dijadikan sebagai antisipasi, yaitu sebagai salah satu penyebab munculnya intoleransi dan dapat menimbulkan masalah keberagaman, karena ini memang dapat menjadi pemicu konflik keagamaan di Indonesia. Penyebab kerawanan intolerasi tersebut sebagaimana diuraikan oleh Puslitbang Kehidupan Keagamaan Badan Litbang dan Diklat Departemen Agama sebagaimana pembahasan di atas. Menjaga toleransi umat beragama dan toleransi umat seagama seperti ini masuk dalam bagian religious culture di sekolah, dirasakan guru dan tata usaha SMP Negeri 2 Arut Selatan sangat membantu dalam upaya menanggulangi konflik dan bukan memunculkan konflik.

Gambaran di atas dapat disimpulkan pertama, kekuatan religious sekolah mereka anggap mampu menjadikan orang-orang di sekolah sebagai manusia yang adil, beradab, berakhlak baik, dan terpuji; kedua, berpotensi untuk membantu tradisi berfikir, bersikap dewasa, terbuka serta toleransi; ketiga, sebagai pengikat anggota sekolah dari generasi ke generasi untuk bisa hidup berdampingan secara dinamis dan rukun. Konflik adalah pertentangan yang bersifat langsung dan disadari antara individu-individu atau kelompok untuk mencapai tujuan yang sama. Kekalahan pihak

\footnotetext{
${ }^{20}$ Ahmadi Hasan, Adad Badamai..., h. 23.

${ }^{21}$ Isre, Moh. Soleh (ed.), Konflik Etnis..., h. 270.
} 
lawan dianggap sangat penting dalam mencapai tujuan. Dalam konflik, orientasi tertuju ke pihak lawan lebih penting dari pada objek yang hendak dicapai. ${ }^{22}$

Jadi, pelaksanaan toleransi di SMP Negeri 2 Arut Selatan, sejak awal berdirinya sampai sekarang, mengimplementasikan sikap toleransi antar agama dan antar umat seagama dengan baik dan selalu menjaga, serta dipertahankan. Meskipun pernah terjadi sesuatu yang hampir mengarah pada intoleransi beragama, tetapi dapat dikelola oleh guru dan tata usaha sekolah yang dimediasi melalui kepala sekolah sebagai penanggung jawab. Sikap ini sesuai dengan hasil rumusan dialog pengembangan wawasan multikultur antar pemuka agama pusat dan pemuka agama Provinsi Kalimantan Tengah, pada tanggal 13 s.d. 15 Oktober 2003. Menteri Agama RI dalam sambutan tertulisnya dibacakan oleh Kepala Balitbang Agama dan Diklat Keagamaan Departemen Agama antara lain menyampaikan, agar perbedaan menjadi asset yang harus dikembangkan, maka terletak pada bagaimana cara mengelola perbedaan-perbedaan itu. ${ }^{23}$ Bukanlah sebaliknya, menjadi masalah yang bisa mengarah pada konflik yang dibesar-besarkan sehingga berpeluang menjadi konflik.

Sikap toleransi beragama di SMP Negeri 2 Arut Selatan yang dipunyai warga sekolah, dan diaktualisasikan dalam kinerjanya yang sarat dengan kemajemukan religious culture, merupakan bagian dari nilai religious dan nilai culture yang harus ada, karena sebuah keniscayaan dan sangat relevan untuk kemajuan sekolah sekaligus menjadi kemujuan untuk semua. Memang diperlukan suatu strategi/upaya untuk mengembangkan sikap toleransi tersebut. Sebagaimana yang sudah dilakukan oleh kepala sekolah serta menganjurkan agar selalu menjaga toleransi dengan cara: mengintegrasikan nilai budaya toleransi dalam mata pelajaran umum, secara inverbalistik dan informalistik melalui tatap muka proses belajar mengajar dalam

\footnotetext{
${ }^{22}$ Ahmad Fedyani Syaifuddin, Konflik dan Integrasi Perbedaan Paham Dalam Agama Islam, (Jakarta: CV.Rajawali, 1986), h. 7.

${ }^{23}$ Departemen Agama RI Badan Litbang dan Diklat, Merajut Kerukunan Umat Beragama Melalui Dialog Pengembangan Wawasan Multikultur, (Jakarta: Puslitbang Kehidupan Beragama, 2008), h. 332.
} 
kelas maupun di luar kelas; mengembangkan strategi pembelajaran alternatif; semua guru memasukkan pesan-pesan moral agama secara umum kepada peserta didik. Kebijakan yang lebih besar tentang peran agama di sekolah-sekolah tertentu kiranya di luar pengaruh guru, akan tetapi guru dapat memainkan peran vital dalam mengajarkan tentang agama dan nilainya serta memberikan teladan tentang sikap menghormati dan toleransi terhadap berbagai macam keyakinan religious. ${ }^{24}$

Implementasi toleransi beragama di SMP Negeri 2 Arut Selatan yang sudah menjadi bagian dari culture sekolah dan merupakan karakter sekolah, sesuai dengan harapan pemerintah Indonesia melalui hasil rumusan dialog pengembangan wawasan multikultur antar pemuka agama pusat dan pemuka agama Propinsi Kalimantan Tengah Tanggal 13 s.d 15 Oktober 2003. Menteri agama dalam sambutan tertulisnya yang dibacakan oleh kepala badan Litbang Agama dan Diklat Keagamaan Departemen Agama antara lain menyampaikan agar perbedaan menjadi asset yang harus dikembangkan. Terletak pada bagaimana cara mengelola perbedaan-perbedaan itu. ${ }^{25}$

Paparan di atas menggambarkan bahwa penganut agama mayoritas di sekolah turut mempengaruhi terhadap pelaksanaan religious culture-nya, dengan demikian berarti mayoritas beragama di SMP Negeri 2 Arut Selatan, mampu menunjukkan sebagai pengayom. Hal ini secara umum sudah berlaku di seluruh nusantara bagi yang muslimnya mayoritas. Sebagaimana yang diungkapkan oleh Nurcholis Madjid, bahwa "Islam telah membuktikan kemampuannya secara meyakinkan dalam melaksanakan toleransi dan pluralisme secara unik dalam sejarah agama-agama, di mana agama Islam merupakan anutan mayoritas, agama-agama lain tidak mengalami kesulitan berarti. ${ }^{26}$ Seiring dengan kenyataan tersebut personil yang beragama Islam

\footnotetext{
${ }^{24}$ Richard I. Arends, Learning To Teach, terj. Helly Prajitno Soetjipto dan Sri Mulyantini Soetjipto, dengan Judul, Belajar untuk Mengajar, (Yogyakarta: Pustaka Pelajar, 2008), h. 71.

${ }^{25}$ Departemen Agama RI Badan Litbang dan Diklat, Merajut Kerukunan... h. 332.

${ }^{26}$ Nurcholis Madjid, Islam, Doktrin..., h. 7-8.
} 
di tiap lembaga mana pun termasuk sekolah, dan harus menjadi golongan yang terbuka, yang bisa tampil dengan rasa percaya diri, dan bersikap sebagai pamong yang mengayomi golongan-golongan lainnya. Hal ini karena dalam Islam memang sudah ada doktrin tentang menjalankan agama secara universal, "Islam memberi landasan religious bagi para pemeluk untuk menerima keberadaan agama lain dan mengadakan hubungan baik bagi para pemeluknya". ${ }^{27}$

Agree in disegreement adalah kebijakan pemerintah pada zaman Menteri Agama Mukti Ali yang memperkenalkan prinsip dasar kerukunan. Kemudian pada masa Menteri Agama Alamsyah Ratu Perwira Negara, mengembangkan pendekatan yang diberi nama "trilogy kerukunan", yakni kerukunan intern, antar dan antara umat beragama dengan pemerintah. Selanjutnya masa Menteri Agama Munawir Sadzali sampai masa Menteri Agama Malik Fajar, maksud lainnya juga untuk meneruskan kebijakan yang disebut dengan kerukunan dinamis, bertujuan untuk membangun kehidupan sosial yang lebih luas di antara umat beragama. Zaman Menteri Agama Tolchah Hasan dan Said Agil Husin Al Munawar, lebih mengarahkan pada perwujudan sikap kemanusiaan dengan kebijakan "pengembangan wawasan multikultural" juga pendekatan yang bersifat "bottom up". Kehadiran Departemen Agama secara struktural dan secara historis fungsional di Indonesia yang didirikan pada tanggal 3 Januari 1946 merupakan implementasi dari UUD 1945, yakni negara berdasarkan atas Ketuhanan Yang Maha Esa dan negara menjamin kemerdekaan tiaptiap penduduk untuk memeluk agamanya.

\section{Penutup}

\section{Simpulan}

Religious culture dalam bentuk toleransi beragama di SMP Negeri 2 Arut Selatan berkembang dengan saling memahami, menjaga, dan membangun sebuah

\footnotetext{
${ }^{27}$ M. Ilham Maskhuri Hamdie, Pluralitas Agama..., h. 15.
} 
sistem melalui komitmen dan mengutamakan team work; toleransi beragama merupakan salah satu bentuk kekayaan religious culture di SMP Negeri 2 Arut Selatan, dilakukan dengan cara: memfasilitasi dan memberikan kebebasan beribadah; melaksanakan hari besar keagamaan bersama dengan batas yang lazim; saling berkunjung dan mengucapkan selamat bagi sebagian yang melakukan; dan, menghargai aturan tentang makanan/minuman yang halal dan haram.

\section{Saran-Saran}

Sebagaimana simpulan di atas, penulis menyarankan sekaligus sebagai harapan sebagai berikut:

1. Dinas Pendidikan Pemuda dan Olah Raga kabupaten, menyerahkan sepenuhnya kepada pihak sekolah untuk mengembangkan toleransi beragama sesuai dengan kompetensi sekolah, sehingga mempunyai karakteristik tersendiri, selanjutnya akan menjadi kekayaan kabupaten setempat.

2. Pendidik dan tenaga kependidikan, seharusnya bertoleransi dalam pelaksanaan tugas dan fungsi masing-masing, karena ini sebuah kebutuhan dan keniscayaan.

3. SMP Negeri 2 Arut Selatan, terus mengembangkan sikap religious culture toleransi beragama sebagai karakter sekolah, sehingga dapat menjadi model bagi sekolah lain yang berkarakteristik sama.

4. Peneliti berikutnya, dapat melanjutkan penelitian tentang religious culture dalam kehidupan bermasyarakat, dengan harapan menjadi informasi dan kontribusi pemikiran setelah penulis.

\section{DAFTAR PUSTAKA}


E-ISSN : 2580-7056, ISSN : 2580-7064

Pascasarjana IAIN Palangka Raya

Arends, Richard I., Learning To Teach, terj. Helly Prajitno Soetjipto dan Sri Mulyantini Soetjipto, dengan Judul, Belajar untuk Mengajar, Yogyakarta: Pustaka Pelajar, 2008.

Buseri, Kamrani, Reinventing Pendidikan Islam: Menggagas Kembali Pendidikan Islam yang Lebih Baik, Banjarmasin: Antasari Press, 2010.

Departemen Agama RI Badan Litbang dan Diklat, Merajut Kerukunan Umat Beragama Melalui Dialog Pengembangan Wawasan Multikultur, Jakarta: Puslitbang Kehidupan Beragama, 2008.

Fedyani Syaifuddin, Ahmad, Konflik dan Integrasi Perbedaan Paham Dalam Agama Islam, Jakarta: CV.Rajawali, 1986.

Hasan, Ahmadi, Adad Badamai: Interaksi Hukum Islam dan Huklum Adat pada Masyarakat Banjar, Banjarmasin: Antasari Press, 2007.

Hendrawan, Sanerya, Spiritual Managemen, Bandung: Mizan, 2009.

Hidayat, Komarudin, Tragedi Raja Midas, Moralitas Agama dan Krisis Modernisme, Jakarta, Paramadina: 1998.

Isre, Moh. Soleh (ed.), Konflik Etnis Religius Indonesia Kontemporer, Jakarta: Proyek Peningkatan Pengkajian Kerukunan Hidup Umat Beragama, Puslitbang Kehidupan Beragama, Badan Litbang Agama dan Diklat Keagamaan Departemen Agama RI, 2003.

Kementerian Agama, Panduan Model Kurikulum PAI Berbasis Multikultur SMP, Dirjen Pendidikan Islam pada Sekolah, 2000.

Madjid, Nurcholis, Islam, Doktrin dan Peradaban: Sebuah Telaah Kritis Tentang Masalah Keimanan, Kemanusiaan, dan Kemoderenan, Jakarta, Paramadina: 1995.

Maskhuri Hamdie, M. Ilham, Pluralitas Agama Menuju Dialog Antar Agama; Talaah Dimensi Sufistik Pemikiran Nurcholis Madjid, Banjarmasin: Antasari Pres, 2006.

Pidarta, Made, Landas Kependidikan: Stimulus Ilmu Pendidikan Bercorak Indonesia, Jakarta: Rineka Cipta, 2007. 
E-ISSN : 2580-7056, ISSN : 2580-7064

Pascasarjana IAIN Palangka Raya

Puslitbang Kehidupan Beragama, Kompilasi Kebijakan dan Peraturan Perundangundangan Kerukunan Umat Beragama, Jakarta: Balitbang \& Litbang \& Diklat Puslitbang Kehidupan Keagamaan Depag RI, 2008.

Sanjaya, Wina, Kurikulum Pembelajaran, Teori dan Praktik Pengembangan Kurikulum Satuan Pendidikan, Jakarta: Kencana Prenada Media Grouf, 2009.

Shihab, M. Quraisy, "Membumikan" Al-Quran: Fungsi dan Peran Wahyu Dalam Kehidupan Masyarakat, Bandung: Mizan, 1992. 